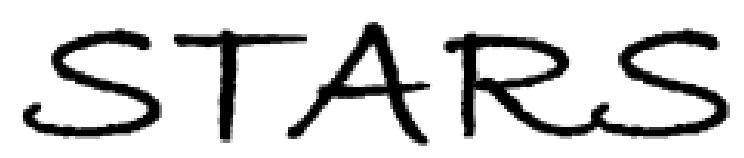

University of Central Florida

STARS

2-16-1989

\title{
Thermal Performance Monitoring Results From The Residential Standards Demonstration Program
}

Florida Solar Energy Center

Danny Parker

Florida Solar Energy Center, dparker@fsec.ucf.edu

Part of the Energy Systems Commons

Find similar works at: https://stars.library.ucf.edu/fsec

University of Central Florida Libraries http://library.ucf.edu

This Contract Report is brought to you for free and open access by STARS. It has been accepted for inclusion in FSEC Energy Research Center ${ }^{\circledR}$ by an authorized administrator of STARS. For more information, please contact

STARS@ucf.edu.

\section{STARS Citation}

Florida Solar Energy Center and Parker, Danny, "Thermal Performance Monitoring Results From The Residential Standards Demonstration Program" (1989). FSEC Energy Research Center ${ }^{\circledR} .899$. https://stars.library.ucf.edu/fsec/899

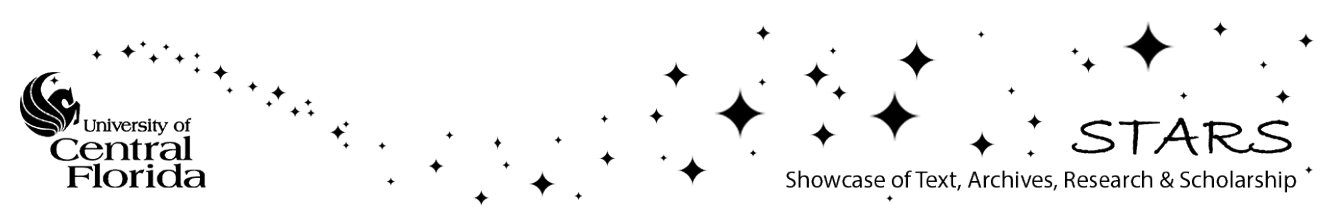




\title{
Thermal Performance Monitoring Results from the Residential Standards Demonstration Program
}

\author{
Authors \\ Danny S. Parker \\ Original Publication
}

Parker, D., "Thermal Performance Monitoring Results from the Residential Standards Demonstration Program", Elsevier Sequoia/Printed in The Netherlands, February 16, 1989.

\section{Publication Number}

FSEC-CR-1773-89

\author{
Copyright \\ Copyright (C) Florida Solar Energy Center/University of Central Florida \\ 1679 Clearlake Road, Cocoa, Florida 32922, USA \\ (321) 638-1000 \\ All rights reserved.
}

\begin{abstract}
Disclaimer
The Florida Solar Energy Center/University of Central Florida nor any agency thereof, nor any of their employees, makes any warranty, express or implied, or assumes any legal liability or responsibility for the accuracy, completeness, or usefulness of any information, apparatus, product, or process disclosed, or represents that its use would not infringe privately owned rights. Reference herein to any specific commercial product, process, or service by trade name, trademark, manufacturer, or otherwise does not necessarily constitute or imply its endorsement, recommendation, or favoring by the Florida Solar Energy Center/University of Central Florida or any agency thereof. The views and opinions of authors expressed herein do not necessarily state or reflect those of the Florida Solar Energy Center/University of Central Florida or any agency thereof.
\end{abstract}




\title{
Thermal Performance Monitoring Results from the Residential Standards Demonstration Program
}

\author{
DANNY S. PARKER* \\ Northwest Power Planning Council, 850 S.W. Broadway, Portland, OR 97205 (U.S.A.)
}

(Received February 21, 1988; accepted May 8, 1988; revised paper received February 16, 1989)

\section{ABSTRACT}

The Model Conservation Standards (MCS) were developed by the Northwest Power Planning Council in 1983. These standards were designed to save large amounts of space heating energy in new U.S. residential construction in the Pacific Northwest. Creation of the MCS resulted in a desire to demonstrate the actual savings of such energy efficiency standards. The Bonneville Power Administration sponsored the Residential Standards Demonstration Program (RSDP) in 1984 which resulted in the construction of 410 energy-efficient single-family homes in the four-state region. Typically these buildings incorporated design features such as high levels of insulation for attic, walls and floors, triple-glazed windows and airtight construction with heat-recovery ventilation.

These MCS dwellings have been compared against another group of 410 new, but conventional homes in the Northwest to determine the actual savings of such efficiency standards for space heat. Each house was monitored for at least one year using a triple metering system that recorded energy use for space heat, domestic hot water and appliances. Average interior and exterior temperatures were also collected during the monitoring period. Extensive data was assembled from audit and survey information on the construction of the homes, their heating systems and other occupancy-related characteristics. This paper both summarizes results of the RSDP project and scrutinizes certain aspects associated with the buildings' monitored thermal performance.

*Current address: Florida Solar Energy Center, 300 State Road 401, Cape Canaveral, FL 32920, U.S.A.
Monitored space heat savings for the energy-efficient MCS houses compared to the control buildings averaged $27.5 \mathrm{kWh} / \mathrm{m}^{2}$ of floor area for the overall sample of 524 houses. Data analysis showed that differing levels of insulation in the buildings is the most powerful explanation for these differences. The program also illustrated how collection of simple end-use metering data can provide insight into the energy-use characteristics of residential buildings. Among other findings, we discovered that the type of heating system plays a large role in determining the relative efficiency of electrically heated houses. Residences with electric forced-air heating systems used an average of $15.9 \mathrm{kWh} / \mathrm{m}^{2}$ more space heating energy than those without them. Houses with heat pumps or those using wood as their primary heat source used much less space heat electricity. We also discovered that houses with fireplaces tended to use more space heat energy.

The study also examined infiltration and ventilation-related measures on the houses using fan pressurization and perfluorocarbon tracer gas (PFT) tests. We found that the $R S D P$ control homes, intended to be representative of current building practice in the Pacific Northwest, have relatively low rates of natural air infiltration - an average of about 0.4 air changes per hour $(A C H)$. The natural air infiltration rate of the MCS houses tended to be tighter, on the order of $0.25 \mathrm{ACH}$. Air-to-air heat exchangers in the MCS houses were used an average of $9 h$ per day, and increased the overall ventilation rate in these homes to about $0.35 \mathrm{ACH}$.

\section{INTRODUCTION}

The typical insulation characteristics of new current-practice homes in the Pacific 
TABLE 1

Assumed insulation and ventilation levels for new current-practice housing in the U.S. Pacific Northwest

\begin{tabular}{llll}
\hline Building component & \multicolumn{3}{l}{ RSI value $\left(\mathrm{m}^{2}{ }^{\circ} \mathrm{C} / \mathrm{W}\right)$} \\
\cline { 2 - 4 } & Zone 1 & Zone 2 & Zone 3 \\
\hline Ceiling/Attics & 5.3 & 5.3 & 6.7 \\
Walls & 1.9 & 1.9 & 3.3 \\
Below-grade walls & 0.9 & 1.9 & 1.9 \\
Floor & 1.9 & 1.9 & 3.3 \\
Slab perimeter & 0.9 & 0.9 & 0.9 \\
Doors & 0.4 & 0.4 & 0.4 \\
Windows & DG & DG & DGTB \\
Infiltration & 0.6 ACH & 0.6 ACH & $0.6 \mathrm{ACH}$ \\
Ventilation & \multicolumn{4}{l}{ No mechanical ventilation } \\
& required
\end{tabular}

DG = Double-glazed $;$ DGTB $=$ double-glazed thermally broken frame.

$\mathrm{ACH}=$ natural average air changes per hour.
TABLE 2

Assumed insulation and ventilation levels for the Model Conservation Standards

\begin{tabular}{llll}
\hline Building component & \multicolumn{3}{c}{ RSI value $\left(\mathrm{m}^{2}{ }^{\circ} \mathrm{C} / \mathrm{W}\right)$} \\
\cline { 3 - 4 } & Zone 1 & Zone 2 & Zone 3 \\
\hline Ceiling/Attics & 6.7 & 6.7 & 6.7 \\
Walls & 3.3 & 4.8 & 5.3 \\
Below-grade walls & 3.3 & 3.3 & 3.3 \\
Floor & 3.3 & 5.3 & 5.3 \\
Slab perimeter & 1.8 & 1.8 & 1.8 \\
Doors & 0.9 & 0.9 & 0.9 \\
Windows & TGTB & TGTB & TGTB \\
Infiltration & 0.1 ACH & 0.1 ACH & $0.1 \mathrm{ACH}$ \\
Ventilation & 0.5 ACH with 60\% heat \\
& recovery & \\
\end{tabular}

TGTB = Triple-glazed with thermally broken frame, or double-glazed with low-emissive film.

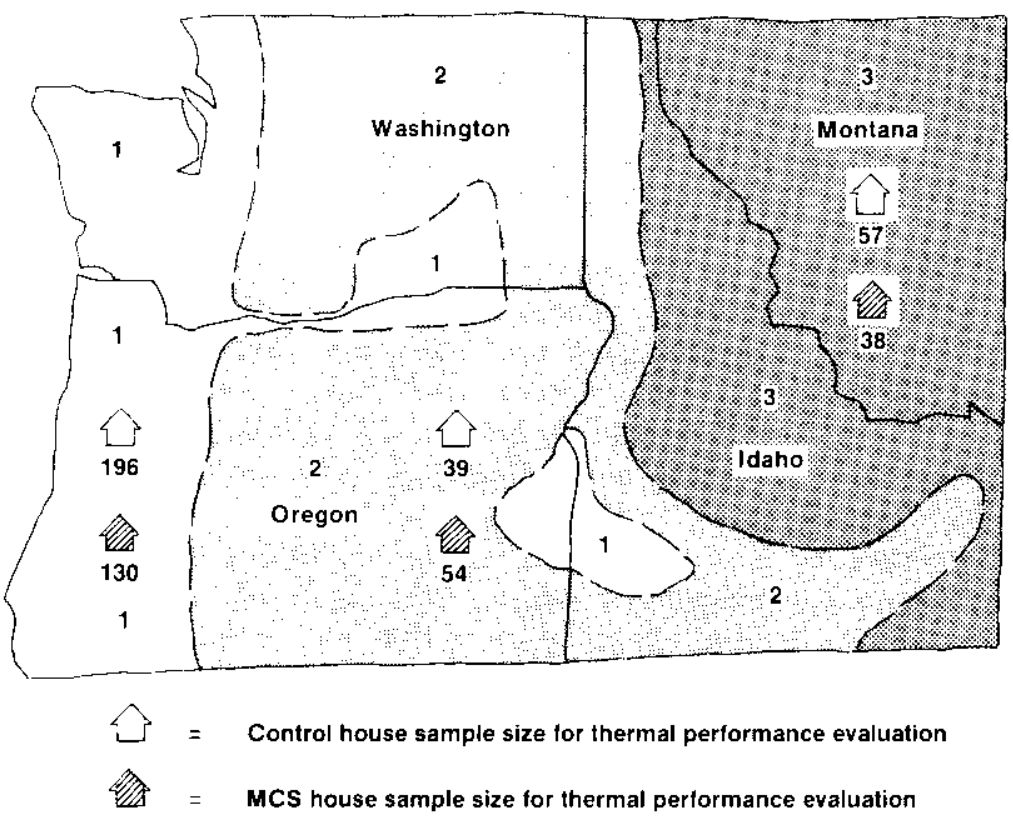

Fig. 1. Climate zones in the Pacific Northwest.

Northwest are given in Table 1 for each of the three climate zones. The climate zones are illustrated in Fig. 1. Table 2 lists the comparative requirements for the energy-efficient Model Conservation Standards (MCS) houses. Climate zone 1 is defined as the mild coastal climate region with less than $3333{ }^{\circ} \mathrm{C}$ heating degree-days. Heating degree-days (HDD) are defined at an $18.3^{\circ}$ base. Climate zone 2 is defined as having between 3333 and 4167
HDD and zone 3 with more than the latter figure.

There have been two phases of the energy performance monitoring. The RSDP project sub-metered space heat, hot water and appliance electricity [1]. The End-Use Load and Conservation Assessment Program (ELCAP) collected much more detailed information on a subset of RSDP homes: multi-zone temperatures, electricity consumption of various 
appliances, wood-stove operation and other data. This paper primarily focuses on the sub-metered RSDP results.

The zone-weighted estimated space heat savings using computer simulation was calculated to average $49.9 \mathrm{kWh} / \mathrm{m}^{2}$ for MCS over current-practice buildings. The estimated level of savings was higher than that realized. The project has shown average annual space heat savings of $26.9 \mathrm{kWh} / \mathrm{m}^{2}$ of floor area when comparing the energy-efficient homes against the current-practice buildings. However, as will be shown, the RSDP data have proved an abundant source for other residential energyrelated information. Analysis of this data base allows unique insight into the determinants of building thermal performance and conservation measure effectiveness. Based on analysis presented later in the paper, we believe that most of the over-predicted savings of the MCS resulted from poor assumptions for the simulation about the airtightness of currentpractice houses in the Pacific Northwest.

\section{RSDP PROGRAM ENERGY PERFORMANCE SUMMARY}

The tables below summarize data for 820 homes in the RSDP program. The primary source is a data base created by the Lawrence Berkeley Laboratory [2]. Analysis of these data shows the energy use of both currentpractice and MCS homes. The average electricity consumption by end use is summarized in Tables $3-5$. As shown, the consumption of space heating electricity was substantially less for the energy-efficient homes.

The RSDP houses saved an average of 2009 - $4320 \mathrm{kWh}$ of space heat against the conventional houses. Consumption for appliances and hot water in the energy-efficient houses was nearly double that for space heating. MCS homes in zones 1 and 2 used more appliance electricity than did the control houses.

\section{ANALYSIS OF THE SPACE HEAT ELECTRICITY CONSUMPTION}

The Model Conservation Standards were designed to save space heating energy. As a consequence, most of the savings of the MCS
TABLE 3

Annual RSDP energy performance results for climate zone 1 (<3333 ${ }^{\circ} \mathrm{C}$ heating degree-days) $1985 \cdot 1986$

\begin{tabular}{llcl}
\hline & $\begin{array}{l}\text { Space heat } \\
(\mathrm{kWh})\end{array}$ & $\begin{array}{l}\text { Hotwater } \\
(\mathrm{kWh})\end{array}$ & $\begin{array}{l}\text { Appliances } \\
(\mathrm{kWh})\end{array}$ \\
\hline Control & 8877 & 4646 & 6939 \\
MCS & 6529 & 4484 & 7690 \\
Savings & 2348 & 162 & -751 \\
\hline
\end{tabular}

TABLE 4

Annual RSDP performance results for climate zone 2 (3333-4167 ${ }^{\circ} \mathrm{C}$ heating degree-days) $1985-1986$

\begin{tabular}{llll}
\hline & $\begin{array}{l}\text { Space heat } \\
(\mathrm{kWh})\end{array}$ & $\begin{array}{l}\text { Hot water } \\
(\mathrm{kWh})\end{array}$ & $\begin{array}{l}\text { Appliances } \\
(\mathrm{kWh})\end{array}$ \\
\hline Control & 9892 & 5359 & 7483 \\
MCS & 7883 & 4931 & 8210 \\
Savings & 2009 & 428 & -727 \\
\hline
\end{tabular}

TABLE 5

Annual RSDP performance results for climate zone 3 (>4167 ${ }^{\circ} \mathrm{C}$ heating degree-days) $1985 * 1986$

\begin{tabular}{lccc}
\hline & $\begin{array}{l}\text { Space heat } \\
(\mathrm{kWh})\end{array}$ & $\begin{array}{l}\text { Hot water } \\
(\mathrm{kWh})\end{array}$ & $\begin{array}{l}\text { Appliances } \\
(\mathrm{kWh})\end{array}$ \\
\hline Control & 10936 & 5462 & 7123 \\
MCS & 6616 & 5038 & 6411 \\
Savings & 4320 & 424 & 712 \\
\hline
\end{tabular}

are contained in the differences in space heating use. The savings estimates in the Tables below and elsewhere in this report include the statistical uncertainty of the estimates when evaluated at a $90 \%$ confidence level.

The empirical measure that we believe to be most powerful for comparing relative thermal performance of the houses is the submetered space heat consumption normalized by floor area. This is particularly important since MCS homes tended to be somewhat larger. Relevant statistical measures for auxiliary space heat are listed for each climate zone in Table 6. Auxiliary space heat is defined as the amount of electric space heating that is necessary to maintain interior comfort conditions. The sample size is denoted in the various Tables as $N$. 
TABLE 6

Space heat use by zone

\begin{tabular}{|c|c|c|c|c|c|}
\hline Zone & $\begin{array}{l}\text { Floor area } \\
\left(\mathrm{m}^{2}\right)\end{array}$ & $\begin{array}{l}\text { Mean } \\
\left(\mathrm{kWh} / \mathrm{m}^{2}\right)\end{array}$ & $\begin{array}{l}\text { S.D.* } \\
\left(\mathrm{kWh} / \mathrm{m}^{2}\right)\end{array}$ & $\begin{array}{l}\text { Median } \\
\left(\mathrm{kWh} / \mathrm{m}^{2}\right)\end{array}$ & $N$ \\
\hline \multicolumn{6}{|l|}{ Zone 1} \\
\hline Control & 144.3 & 62.3 & 27.2 & 57.4 & 158 \\
\hline MCS & 183.8 & 35.4 & 15.2 & 34.0 & 99 \\
\hline Difference & 39.5 & $26.9 \pm 4.3$ & & 23.4 & \\
\hline \multicolumn{6}{|l|}{ Zone 2} \\
\hline Control & 163.1 & 63.8 & 29.2 & 56.3 & 32 \\
\hline MCS & 207.1 & 39.5 & 12.4 & 39.3 & 39 \\
\hline Difference & 44.0 & $24.3 \pm 9.0$ & & 17.0 & \\
\hline \multicolumn{6}{|l|}{ Zone 3} \\
\hline Control & 165.8 & 68.9 & 32.2 & 65.5 & 54 \\
\hline MCS & 210.5 & 31.1 & 13.3 & 29.5 & 40 \\
\hline Difference & 44.7 & $37.8 \pm 8.0$ & & 36.0 & \\
\hline
\end{tabular}

*S.D. = standard deviation.

A subset of these buildings had complete information on the average interior and ambient temperatures and the length of the monitoring period. This information allows determination of the specific auxiliary heating energy that is commonly used in comparisons of buildings to determine their energy efficiency relative to other structures in differing locations. This measure normalizes auxiliary space heating consumption by temperature difference and floor area. It is summarized for the RSDP-MCS and control buildings in Table 7. Interior and ambient average temperatures over the monitoring period are abbreviated as $T_{\mathrm{int}}$ and $T_{\mathrm{amb}}$, respectively.

Auxiliary heat consumption in the MCS houses evidences the energy efficiency of these structures. Typical specific auxiliary heating energy in residential buildings has been estimated to be on the order of $33-67$ $\mathrm{W} /{ }^{\circ} \mathrm{C}$ day $\mathrm{m}^{2}$ although documentation of this assumption has been chronically lacking [3]. The measured auxiliary heating energy in 50 Class $B$ passive solar buildings averaged $10.6 \mathrm{~W} /{ }^{\circ} \mathrm{C}$ day $\mathrm{m}^{2}$ [4]. In the RSDP project the MCS buildings used still less auxiliary heat $-6.3 \mathrm{~W} /{ }^{\circ} \mathrm{C}$ day $\mathrm{m}^{2}$, and the control group averaged only $11.4 \mathrm{~W} /{ }^{\circ} \mathrm{C}$ day $\mathrm{m}^{2}$. As expected, we find that the MCS structures appear more thermally efficient as we move to the colder climate zones where greater levels of insulation are specified by the standards. We also observe that the control group buildings become more energy-efficient as well as we move to the more severe climate zones. Generally interior temperatures in the MCS houses were higher than in the control group structures. This phenomenon is studied in greater detail later in the paper.

Figure 2 shows the frequency distribution of normalized space heat requirements for the MCS and control houses. The histograms

TABLE 7

Specific auxiliary heating energy by zone

\begin{tabular}{llcrrr}
\hline Zone & Group & $\begin{array}{l}\text { Mean } \\
\left(\mathrm{W} /{ }^{\circ} \mathrm{C} \text { day } \mathrm{m}^{2}\right)\end{array}$ & $\begin{array}{l}T_{\text {int }} \\
\left({ }^{\circ} \mathrm{C}\right)\end{array}$ & $\begin{array}{l}T_{\text {amb }} \\
\left({ }^{\circ} \mathrm{C}\right)\end{array}$ \\
\hline Zone 1 & MCS & 7.1 & 20.4 & 5.9 & 83 \\
& Control & 12.8 & 19.9 & 5.6 & 115 \\
Zone 2 & MCS & 6.1 & 21.6 & 3.7 & 34 \\
& Control & 10.6 & 20.4 & 2.9 & 29 \\
Zone 3 & MCS & 4.6 & 20.9 & 1.5 & 29 \\
& Control & 10.0 & 20.7 & 1.6 & 46 \\
\hline
\end{tabular}


Sample size $=524$

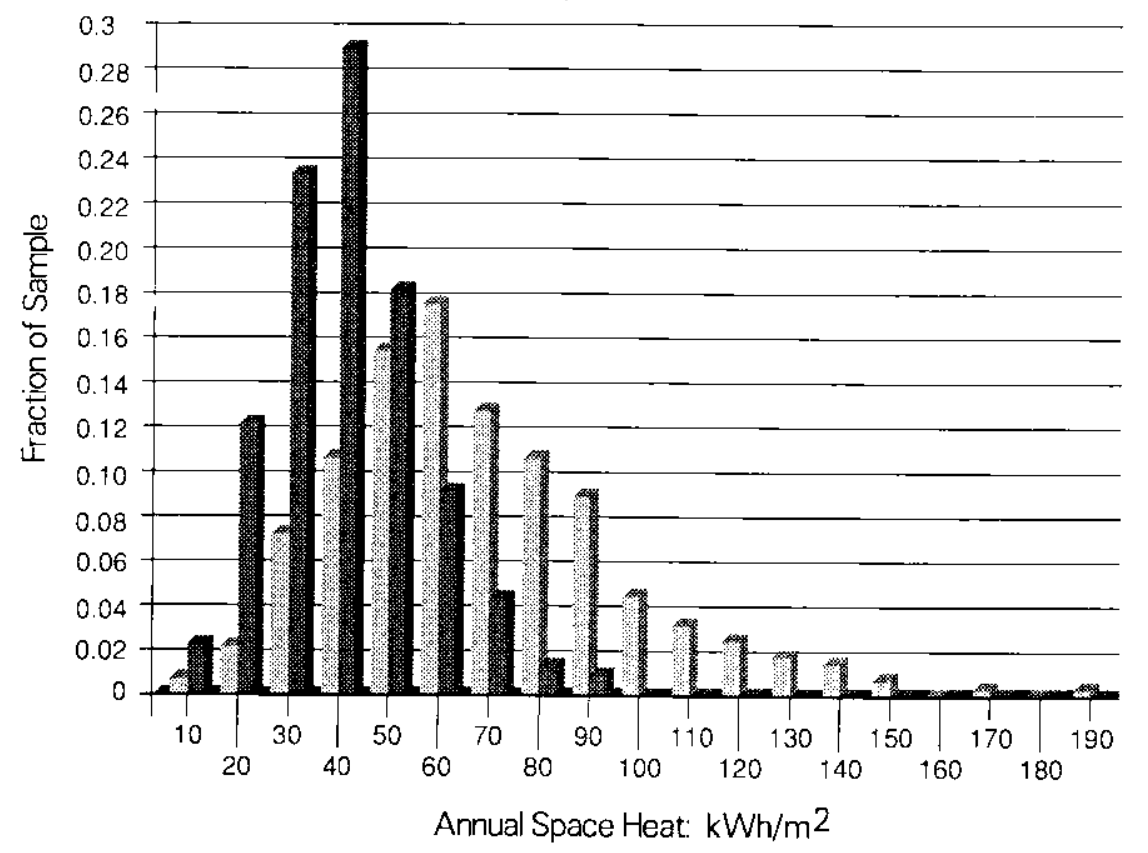

Control Houses

MCS Houses

Fig. 2. Frequency distribution of metered space heat.

show that the MCS houses generally used less space heat electricity than the controls and also showed less variability in consumption.

\section{THE SIGNIFICANCE OF HEATING SYSTEM TYPE}

In the analysis of RSDP houses we found that heating system type accounted for dramatic differences in electric space heat consumption. In particular, forced-air electric heating systems used considerably more space heat per square meter than baseboard electric heating systems.

In the MCS houses where attention had been paid to minimizing exterior duct runs and insulating them where they passed through unconditioned spaces, the average forced-air heating system used only $5.0 \pm 3.9$ $\mathrm{kWh} / \mathrm{m}^{2}$ more than did the baseboard systems - barely of statistical significance. This was also true of all differences in the MCS group. The group of energy-efficient structures are homogenous in character and only forced-air systems were significantly different. However, differences in electricity consumption between heating system types within the control group were greatly ampli- fied. These results are shown by the variable width box plots shown in Fig. 3 (the width of the box indicates the relative sample size). Other measures of central tendency and dispersion are given in Tables 8 and 9 .

Forced-air systems used $15.1 \pm 6.7 \mathrm{kWh} / \mathrm{m}^{2}$ more than did baseboard systems. Overall, this suggests that poor performance is likely unless forced-air electric systems are installed with attention to reducing duct losses. Analysis of the data indicated that with other factors held constant, forced-air systems in the control group may be achieving delivered heating system efficiencies of only $79 \%( \pm 7 \%)$ relative to baseboard systems. In light of recent simulation results of forced-air system efficiencies by the ASHRAE SP 43 committee [5], this should not come as too much of a surprise.

As expected, heat-pump heated houses evidenced superior space heating performance. Control group heat-pump residences used $26.9 \pm 16.5 \mathrm{kWh} / \mathrm{m}^{2}$ less space heat than the rest of that population. The relative similarity of heat-pump heated houses to other types for the MCS group reflects the fact that the MCS allows heat-pump heated houses the option of using less stringent levels of insulation in the building shell. Most RSDP-MCS 


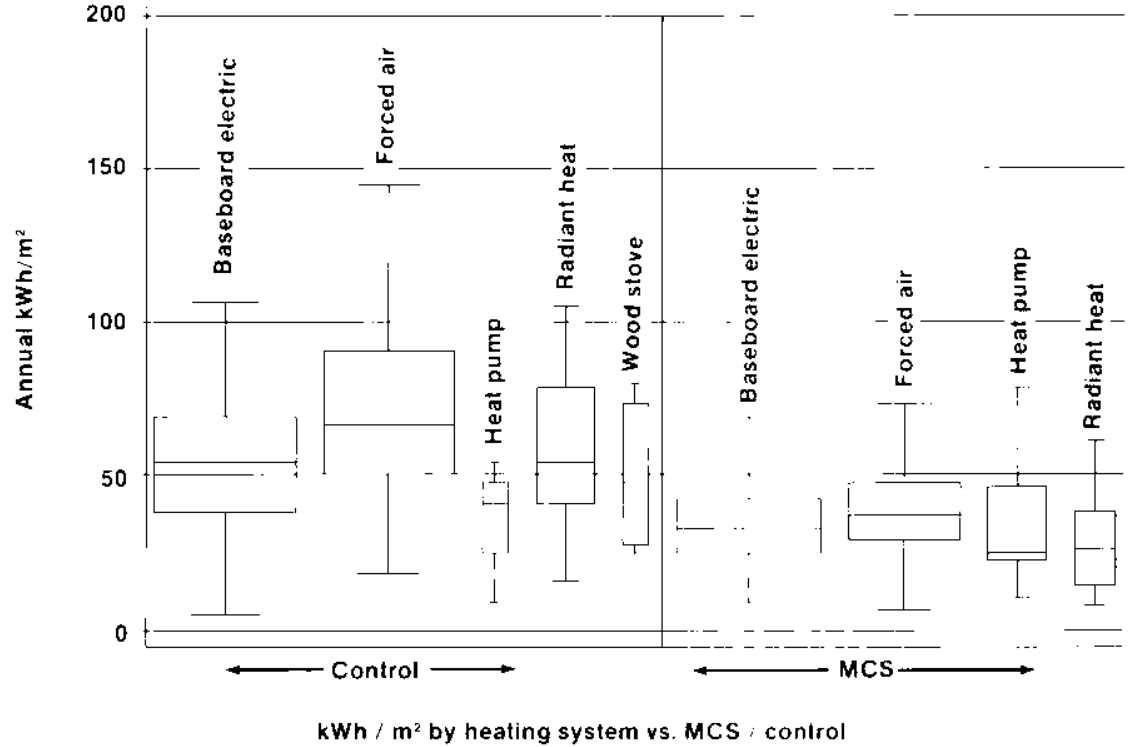

Fig. 3. Box plots of space heat by heating system type.

TABLE 8

Space heat against primary heating system type for MCS house

\begin{tabular}{|c|c|c|c|c|}
\hline Heating system type & $\begin{array}{l}\text { Mean } \\
\left(\mathrm{kWh} / \mathrm{m}^{2}\right)\end{array}$ & $\begin{array}{l}\text { S.D.* } \\
\left(\mathrm{kWh} / \mathrm{m}^{2}\right)\end{array}$ & $\begin{array}{l}\text { Median } \\
\left(\mathrm{kWh} / \mathrm{m}^{2}\right)\end{array}$ & $N$ \\
\hline Baseboard electric & 34.3 & 13.9 & 33.4 & 115 \\
\hline Forced-air electric & 39.3 & 16.3 & 37.2 & 67 \\
\hline Heat pump & 37.9 & 17.7 & 25.2 & 19 \\
\hline Radiant electric & 28.2 & 16.3 & 25.9 & 10 \\
\hline
\end{tabular}

*S.D. = standard deviation.

TABLE 9

Space heat against heating system type for control houses

\begin{tabular}{llllr}
\hline Heating system type & $\begin{array}{l}\text { Mean } \\
\left(\mathrm{kWh} / \mathrm{m}^{2}\right)\end{array}$ & $\begin{array}{l}\text { S.D.* } \\
\left(\mathrm{kWh} / \mathrm{m}^{2}\right)\end{array}$ & $\begin{array}{l}\text { Median } \\
\left(\mathrm{kWh} / \mathrm{m}^{2}\right)\end{array}$ \\
\hline Baseboard electric & 56.8 & 28.3 & 53.9 & $N$ \\
Forced-air electric & 71.9 & 29.1 & 66.0 & 91 \\
Heat pump & 36.3 & 19.7 & 41.6 & 4 \\
Radiant electric & 57.8 & 22.7 & 54.8 & 4 \\
Wood stove & 50.3 & 26.7 & 48.3 & 4 \\
\hline
\end{tabular}

*S.D. = standard deviation.

houses with heat pumps took advantage of this option.

Radiant electric heat systems also tended to use slightly less energy for space heat, although the differences were not statistically significant at any acceptable level due to the small sample size ( 29 houses) and the variability in the data.
The above findings were subjected to further statistical tests to establish their veracity. In Fig. 4, a two-way residual plot shows the differences in space heat consumption with respect to both heating system type and MCS versus control structures. The plot was constructed using a robust statistical procedure that iteratively removes medians 


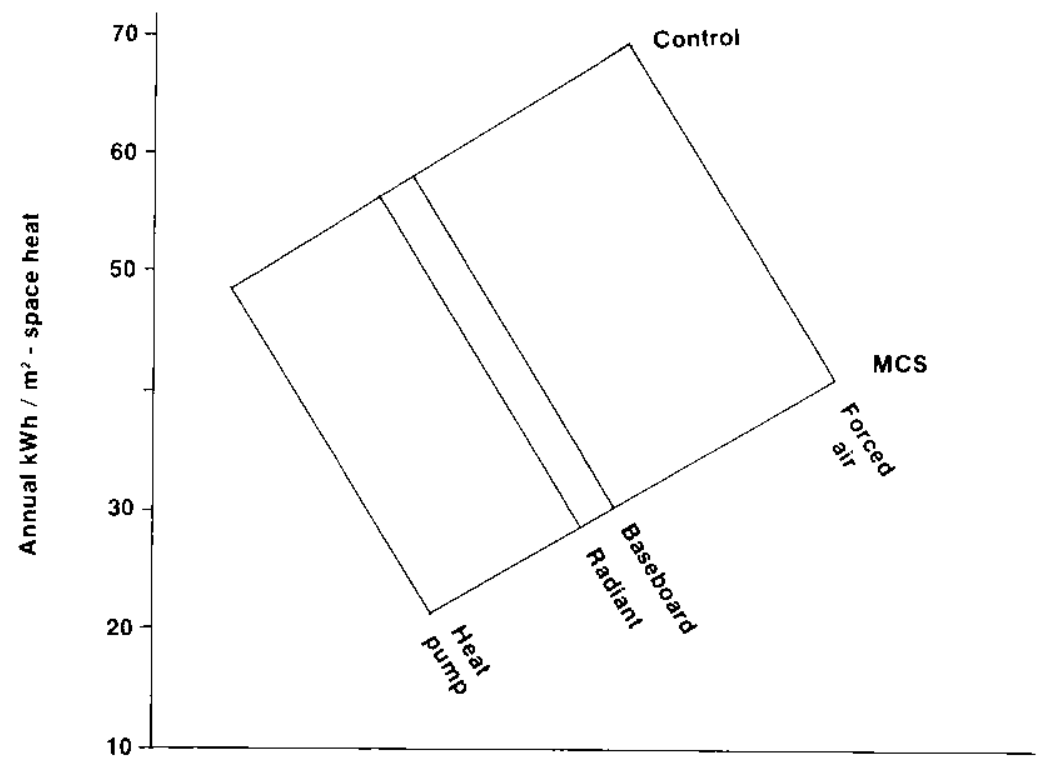

Fig. 4. Two-way residual plot of the effect of heating system type on MCS and control annual space heating.

to establish two-way effects [6]. The result provides visual confirmation of our conclusion regarding both the savings of MCS houses and the relative effects of heating system type.

Note that those houses whose primary heat source is a wood stove are omitted from the analysis. This is done because these houses were all from the control group. However, within the control sample, four dwellings claiming to heat primarily with wood stoves used $20 \%$ less electricity for space heat than did the rest of the group $\left(12.7 \pm 6.2 \mathrm{kWh} / \mathrm{m}^{2}\right)$. Occupants of the control group were paid not to burn wood during the monitoring period, although the more detailed ELCAP study has documented evidence of wood burning in some of the houses. On the other hand, control and MCS houses which had a wood stove that was not identified as the primary heat source recorded space heat consumption that was similar to the rest of the sample.

\section{ANALYSIS OF TEMPERATURE DATA}

As previously mentioned, temperatures averaged $0.8{ }^{\circ} \mathrm{C}$ warmer in the MCS houses than in the control structures. This elevated temperature in the MCS homes has a variety of possible explanations. Physically, we expect the 'float' temperature in better insulated buildings to remain higher than in less well insulated ones due to their longer time constant. There is also possibly a behavioral aspect associated with this phenomenon. Occupants of the houses may be maintaining increased comfort levels due to the low expense of heating the houses. Exploratory analysis of the effect of a lower heat loss coefficient and income for the RSDP occupants found the heat loss coefficient to be the larger effect.

We examined the relationship between average winter outdoor temperature and the average maintained indoor temperature. A common assumption in most building simulation and empirical regression models is that the two conditions are independent and unrelated. The average interior temperature is assumed to be a function of occupant comfort rather than subject to other influences. In Fig. 5 we plot the average winter ambient temperature against that maintained inside.

As might be expected, there is a significant scatter in the data as indicative of the differences in building specific thermal comfort levels and occupancy characteristics. However, closer inspection reveals several noteworthy trends. First, we see visual evidence of the above conclusion: control group house occupants generally maintained cooler temperatures than in MCS houses. A second, more provocative trend shows that average indoor temperatures are influenced by outdoor temperatures. Regression of indoor temperature dependence on outdoor temperature and other related parameters disclosed some intriguing results: 


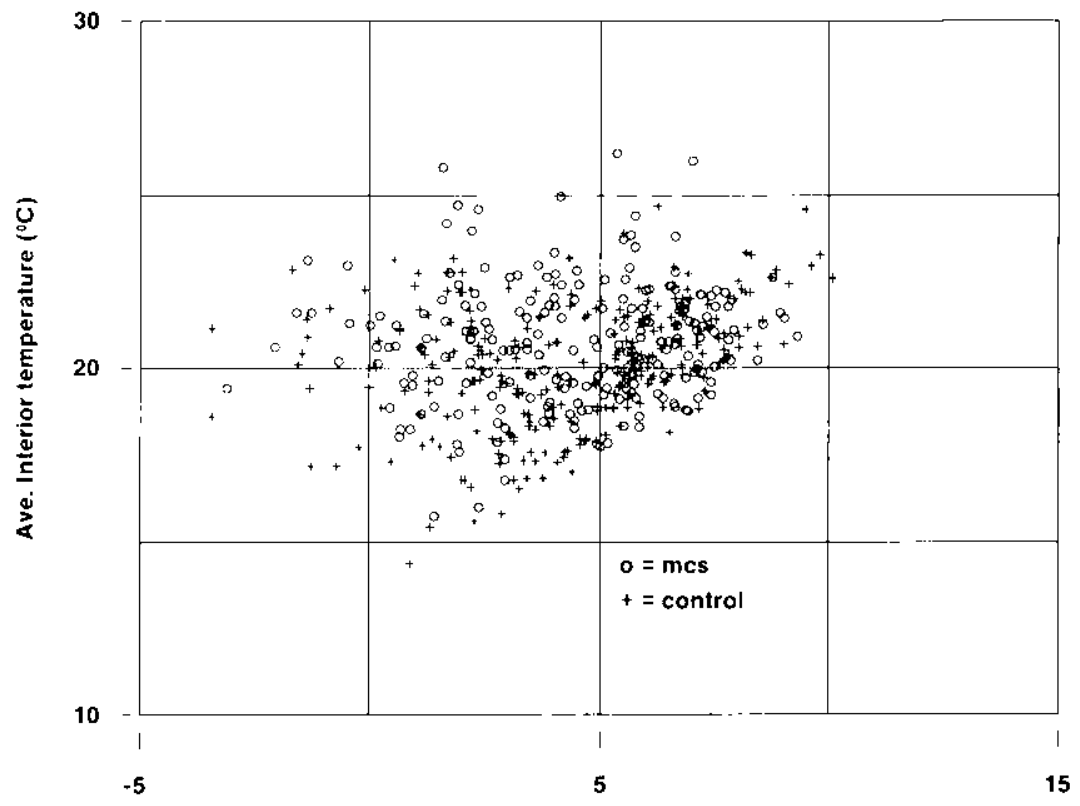

Ave. ambient temperature $\left({ }^{\circ} \mathrm{C}\right)$

Fig. 5. Relationship of interior and ambient temperatures.

$$
\begin{aligned}
T_{\mathrm{int}}= & 17.12(\text { zone } 1)+ \\
& {[37.75] } \\
& +0.42(\mathrm{MCS})-0.0023(\mathrm{UA})
\end{aligned}
$$

$R^{2}=0.36$; sample size $=258$, where

$T_{\text {int }}=$ average interior temperature $\left({ }^{\circ} \mathrm{C}\right)$ during the monitoring period.

zone 1 , zone 2 , zone 3 = dummy variable for climate zone $(0,1)$

$T_{\mathrm{amb}}=$ average ambient outside temperature during period $\left({ }^{\circ} \mathrm{C}\right)$

$Q_{\text {int }}=$ estimated internal heat gains $(\mathrm{W} / \mathrm{h})$

MCS $=$ MCS house $=1 ;$ control house $=0$

$U A=$ estimated building heat loss coefficient $\left(\mathrm{W} /{ }^{\circ} \mathrm{C} \mathrm{h}\right)$

The multiple regression model accounted for about $36 \%$ of the variation in internal temperatures. The results show that the temperatures maintained in the houses are sensitive to outdoor temperatures. They also vary according to the climate zone. This is explained by the difference in solar availability from the cloudy climate coastal zone (zone 1) to the clear and cold zone 3 . Interior temperature is also affected by whether or not the dwelling is an MCS home, the level of internal gains from appliances and people, and the heat loss coefficient for the house. All the

coefficients have the expected sign; internal gains raise temperature, a poorly insulated house will tend to depress temperatures. Houses in colder climates will generally maintain cooler temperatures.

Analysis of the temperature data in the RSDP project by other investigators has found that the relationship between indoor and outdoor temperatures was primarily determined by greater magnitude and frequency of thermostat setback during colder periods and higher float temperatures during warmer months [7]. Thus, the critical parameter of interior temperature, widely used in both simulation and analysis methods, likely has bias with respect to outside temperature and occupant behavior associated with thermostat setting.

\section{PHYSICAL BUILDING CHARACTERISTICS}

The study also examined space heating use by house type. Houses were classified into ten 
types by floor configuration and number of stories, Basement control houses used an average of $4.2 \mathrm{kWh} / \mathrm{m}^{2}$ less than non-basement houses although the difference was only significant at an $80 \%$ confidence level. Based on more detailed hourly data in the ELCAP program, part of this difference may be due to the fact that basements are not maintained at the same temperature level as the abovegrade zones even when heated. Also, basement houses tend to have larger floor area on the order of $190 \mathrm{~m}^{2}$ or more. Because of the diminishing ratio of envelope area to floor area, larger houses tend to show lower normalized space heat consumption per square meter. These results indicate that normalizing space heat consumption by floor area leads to a bias in results. Generally, such normalization will show larger buildings to appear more energy-efficient than smaller ones. For the same reason, two-story houses tended to show lower normalized space heat consumption although the differences were not statistically significant.

One structural characteristic did turn out to be significant, however. Analysis of space heat consumption found that the presence of a fireplace in either the MCS or control homes would serve to increase space heat consumption. Control houses with fireplaces used 7.0 $( \pm 6.0) \mathrm{kWh} / \mathrm{m}^{2}$ more than those without them. The difference in the MCS group was $3.3 \mathrm{kWh} / \mathrm{m}^{2}$ although it was only significant at an $80 \%$ level. We believe this additional space heat consumption results because of the additional air infiltration opportunity presented by the chimney. We examined the blower-door estimates for both houses with and without fireplaces and verified this hypothesis. The blower-door air-change-rate estimates indicated that homes with a fireplace would average an air change rate $0.064 \pm$ $0.043 \mathrm{ACH}$ greater than those without them.

\section{MULTIVARIATE ANALYSIS OF SPACE HEAT ELECTRICITY USE}

In order to better understand the interrelationships of various parameters on estimated space heat use of the homes, we analyzed various house, heating system and occupancy characteristics using multivariate regression techniques. The multiple regression model used here represents an exploratory model of the data. The coefficients resulting from such analysis must not be construed as predictive in any sense or significant in terms of their value, but rather representing the relative influences and directions of effect of various factors on space heat energy consumption. The hazards of inappropriate application or interpretation of such analysis are well covered in ref. 8 . In particular, the values for the various coefficients in multiple regression. are unstable unless there is no inter-correlation between the independent variables, an ideal seldom realized in such analysis.

The form of the specification was taken from known theoretical relationships that determine building auxiliary heat demand. In the simplest form, auxiliary heat demand can be written as:

$Q_{\mathrm{aux}}=\frac{L-Q_{\mathrm{int}}-Q_{\mathrm{sol}}}{F_{\mathrm{eff}}}$

where

$Q_{\text {aux }}=$ the auxiliary heat demand $(\mathrm{kWh})$

$L=$ the building thermal heat load over the heating season required to maintain a desired interior temperature $(\mathrm{kWh})$

$Q_{\text {int }}=$ the utilizable internal heat gains from appliances and occupants ( $\mathrm{kWh}$ )

$Q_{\text {sol }}=$ the utilizable solar heat gains from glazed and opaque envelope areas $(\mathrm{kWh})$

$F_{\text {eff }}=$ the average heating system heat delivery efficiency over time.

The determination of the building thermal load is fundamental to this process. In reality $L$ is a complex and dynamic function of a number of heat transfer mechanisms. Conductive heat loss of above-grade surfaces to the outside air temperature and thermal losses to the ground from that portion of the building in contact with the earth, typically dominate the shell loads. Also, all exposed building surfaces are subject to radiative heat losses to the sky and surrounding surfaces.

Air infiltration loads are proportionate to building envelope tightness, the temperature difference between inside and ambient conditions, and incident exterior wind speeds. Ventilation loads depend on the ventilation system characteristics and system operation.

Zoning of rooms, multiple thermostats, heating system heat distribution characteristics, and occupant alteration of associated controls over time poses further complications. 
Likewise, the utilizability of the internal and solar gains are all strongly affected by the building thermal load and heat capacity and distribution of these driving forces over time. Finally, the seasonal efficiency of the auxiliary heating system itself is often affected by the thermal load and partial load characteristics of the furnace as well as the tendency for the heating system to alter house air infiltration characteristics.

In its most rudimentary form, $L$ can be modeled according to Newton's rate equation as the product of a heat loss coefficient for the building and the cumulative temperature difference between the interior set temperature and outside air temperature:

$L=U A \int_{T_{\mathrm{min}}}^{T_{\mathrm{int}}}\left(T_{\mathrm{int}}-T_{\mathrm{amb}}\right) P\left(T_{\mathrm{a}}\right) \mathrm{d} T_{\mathrm{a}}$

where

$U A=$ the overall building heat loss coefficient $\left(\mathrm{W} / \mathrm{h}{ }^{\circ} \mathrm{C}\right)$

$T_{\mathrm{int}}=$ the interior building temperature $\left({ }^{\circ} \mathrm{C}\right)$

$T_{\text {amb }}=$ hourly ambient temperature $\left({ }^{\circ} \mathrm{C}\right)$

$P\left(T_{\mathrm{a}}\right)=$ unit density distribution function for ambient temperature.

In the RSDP data we have the estimated overall $U A$ of most buildings based on the relative envelope areas and their conductances. The infiltration load used is based on predicted air change rates using a blower-door fan pressurization test and the LBL infiltration model [9]. Internal heat gains were estimated for all houses with appliance and occupancy data [10]. The level of internal gains was estimated to average $974 \mathrm{~W}$ for the sample of 426 houses. Since no solar data were available, we assumed that this would manifest in the intercept or disturbance term. Thus, the initial regression for annual space heat was put forth as:

$Q_{\text {aux } k \text { wh }}=U A \times \mathrm{HDH}-Q_{\mathrm{int}}+A+B \ldots$

where

$U A=$ the building heat loss coefficient $\left(\mathrm{W} /{ }^{\circ} \mathrm{C}\right)$ $\mathrm{HDH}=$ the heating degree-hours; the product of the average temperature difference monitored between inside and ambient conditions and the number of hours in the monitoring period

$Q_{\text {int }}=$ the estimated level of internally released heat gains from appliances and people over the monitoring period
$A, \quad B \ldots=$ continuous, discrete or dummy variables from data base characteristics believed to be associated with space heat consumption (e.g., heat pumps, wood-stove use, etc.).

A global sensitivity approach was used to select and discard variables from the model [11] with the requirement that the $t$-statistic for included parameters be in excess of 1.28 , accounting for the degrees of freedom associated with each. A $t$ value of 1.28 was chosen to help prevent variables from being excluded from the regression that have real effects on space heat consumption which might be otherwise overlooked because of variability in the data. Since many of the coefficients showed large standard errors, a robust regression technique was used to check that the least squares results were reliable [8]. Only variables that were relatively stable with respect to the sensitivity tests were retained. The most satisfactory regression had the form:

$$
\begin{gathered}
Q_{\mathrm{aux}_{\mathrm{k} W \mathrm{~h}}}=3170+0.00014(U A \times \mathrm{HDH}) \\
+111.13] \\
+1716 \text { (forced air?) }-9545 \text { (wood stove?) } \\
\quad[3.78] \\
-2759 \text { (heat pump?) }
\end{gathered}
$$

$R^{2}=0.41:$ sample size $=269$, where

$\mathrm{kWh}=$ space heat kilowatt hours over monitoring period

$U A=$ building overall heat loss coefficient $\left(\mathrm{W} /{ }^{\circ} \mathrm{C}\right)$

$\mathrm{HDH}=$ heating degree-hours over the period $\left({ }^{\circ} \mathrm{C} \mathrm{h}\right)$

forced air? = forced-air electric furnace $(1=$ yes, $0=$ no)

wood stove? $=$ wood stove is primary heat source $(1=$ yes, $0=$ no $)$

heat pump? = heat pump in control home ( $1=$ yes, $0=$ no $)$

The regression explains only about $40 \%$ of the variation in the space heat data, as represented by $R$-squared, the coefficient of determination. Even so, the $t$-statistics for the individual variables (the values in brackets) indicate significant influences on the data. The results indicate that the only consistently stable carriers of variation in the space heat data were the estimated heat loss coefficient 
for the building and the differing heating system types in the houses. Thus, our findings are generally consistent with our model given in eqn. (2).

As expected, we found that the most powerful empirical determinant for the difference in space heat consumption resulted from the product of the heat loss coefficients for the houses and the measured heating degreehours at the site. These heat loss coefficients relate the rate of estimated heat loss from each house in terms of the area of the envelope components, their level of insulation and the relative airtightness of the structure. In a separate analysis not presented here, we performed the multiple regression on each component in the $U A$ calculation: attic, walls, glazing, doors, floors and basement components. The results indicated the correct signs for each component and the values for the coefficients were similar with the exception of the floor $U A$, which had a much lower coefficient and larger standard errors. This suggests that the heat loss coefficient for crawlspaces was poorly determined in the calculation procedure.

We did not find the level of internal gains to be a significant determinant of space heat demand. In fact when it was entered into the above regression, it had a positive sign. We believe there are two reasons for its poor estimation. Firstly, as we have seen in the analysis presented in eqn. (1), part of the internal gains is already embodied in the measured interior average temperature. Houses with higher average internal gains also had higher average interior temperatures. Secondly, and perhaps more importantly, we believe there is a dualistic association of appliance energy use with space heat consumption. Physically, a higher level of appliance gains depresses space heat, although such a high level of appliance gains is usually accompanied by greater levels of occupancy which increase space heat demand by decreased zoning of rooms and higher thermostat settings. This phenomenon is covered in greater detail later in the paper.

The results with regard to heating system type reinforce the earlier findings from the simple statistical tests. Houses with forced-air heating systems use considerably more space heat electricity; control houses with heat pumps used less. These findings have also been independently verified in another anal- ysis of a subset of RSDP homes in Washington state [12].

Control houses claiming that a wood stove was their primary heat source (and who presumably used wood during the monitoring period) used much less space heat electricity. This is in general agreement with the reductions in electric space heat found in woodstove heated houses in the Hood River Conservation Project [13].

Since baseboard-heated houses became the reference case with regards to comparison of other space heat system types, we had little way of determining how much of the observed differences were due to zoning of rooms in baseboard-heated structures. We did examine the occupancy survey question which asked whether occupants commonly closed doors to rooms and left them unheated. We found no statistically significant differences between the group claiming to close off and leave rooms unheated, and the other group who did not claim to do so.

\section{INFILTRATION RATE ESTIMATES}

Data from the RSDP project show that conventional houses being built in the Pacific Northwest may be more airtight than conventional wisdom might suggest. In developing the MCS, we assumed that the air change rate in conventionally built houses averaged about 0.6 air changes per hour ( $\mathrm{ACH})$. The latest evidence indicates that actual average air change rates in the RSDP control group may only be on the order of $0.4 \mathrm{ACH}$. Although we remain unsure of how well the RSDP control houses typify current building practice in the Pacific Northwest, the monitoring project has documented a tremendous variability in residential air infiltration rates. Even houses of similar construction were found to have leakage rates that varied up to 10:1.

The MCS houses were made airtight with sealed polyethylene vapor barriers. Along with the tightening, air-to-air heat exchangers were installed to provide sufficient ventilation air. The intent was that the MCS houses would have a natural air change rate (induced by wind and temperature difference) of about $0.1 \mathrm{ACH}$ with another $0.5 \mathrm{ACH}$ of ventilation provided by air-to-air heat exchangers with $60 \%$ of the heat effectively being recovered. 
These tightening measures were deemed particularly important since space heat savings from this measure were estimated by computer simulation to be at least $14.7 \mathrm{kWh} / \mathrm{m}^{2}$ per year for an average $172 \mathrm{~m}^{2}$ house [14]. We believe that a negligible saving from this conservation measure explains most of the difference between our estimated savings for the MCS and the realized savings in the project.

All control and MCS structures were blower-door tested to determine their relative tightness and to use the LBL infiltration algorithm to predict their seasonal natural air change rates. A subset of over 200 houses had in situ air change rates measured with the Brookhaven perfluorocarbon tracer gas test (PFT). According to the PFT measurements, the average as operated air change rate of the MCS houses was about $0.35 \mathrm{ACH}$. Of course, this figure includes the ventilation supplied by the air-to-air heat exchangers so it is impossible to separate out the natural rate of ventilation for the energy-efficient houses.

Using the blower-door correlation technique and normal weather data, the mean air change rate in the control houses was estimated at about 0.55 air changes per hour. Using the PFT technique on a sub-sample of about 120 houses, the mean air change rate in the control group was only on the order of $0.31 \mathrm{ACH}$ during the period December through March of 1985 - 1986. However, the developer of the PFT test procedures has estimated that due to non-uniform mixing and closed off rooms in the MCS and control homes, the results of the PFT test results in the RSDP project should be increased by an average of $34 \%$. This adjustment results in an average estimated air change rate of $0.42 \mathrm{ACH}$ for the monitoring period for the control group of houses. A comparison of PFT air change rates by heating system types shows strong differences between forced-air and non-forced-air systems. We believe this is evidence for increased air leakage from forced-air distribution systems. These results are shown in Table 10.

This difference of $0.17( \pm 0.05) \mathrm{ACH}$ is statistically significant and shows a substantial variation in the PFT results for baseboards and forced-air systems. Since the blower-door test will also pressurize the duct work in forced-air houses, we would expect to see
TABLE 10

Average PFT air change rate against primary heating system type control houses

\begin{tabular}{lcccr}
\hline Heating system & $\begin{array}{l}\text { Mean } \\
\text { value }\end{array}$ & S.D.* & Median & $N$ \\
\hline Electric forced air & 0.41 & 0.18 & 0.36 & 31 \\
Baseboard electric & 0.24 & 0.11 & 0.22 & 45 \\
Radiant electric & 0.22 & 0.11 & 0.24 & 10 \\
Wood stove & 0.18 & 0.20 & 0.17 & 4
\end{tabular}

*S.D. $=$ standard deviation.

similar results for these structures. In fact, the values shown for the same sample (Table 11) for the blower-door results indicates that this is indeed the case. Although both estimating methods show that forced-air houses are leakier, the PFT test indicates a much greater level of magnitude in the differences. We believe the major reason that the blower door technique does not show a greater difference between forced-air and non-forced-air systems is that the LBL model cannot account for the fact that leakage in the duct system is under considerably higher pressure than is leakage located in the building shell. To estimate air leakage rates, the LBL model assumes that all measured leakage is subjected to natural pressure differences arising from wind and thermal buoyancy effects. However, when operating, residential duct systems operate under pressures ranging from 25 to $75 \mathrm{~Pa}$. Thus, leakage within the duct system is exposed to pressure differences that are an order of magnitude higher than commonly encountered weather induced building shell pressures.

The period of December through March of 1985 - 1986 when most of the PFTs were in

TABLE 11

Average estimated blower-door $\mathrm{ACH}$ against primary heating system type control houses

\begin{tabular}{llllr}
\hline Heating system & $\begin{array}{c}\text { Mean } \\
\text { value }\end{array}$ & S.D.* & Median & $N$ \\
\hline Electric board air & 0.56 & 0.22 & 0.57 & 31 \\
Baseboard electric & 0.48 & 0.26 & 0.45 & 45 \\
Radiant electric & 0.56 & 0.36 & 0.54 & 10 \\
Wood stove & 0.65 & 0.22 & 0.61 & 4 \\
\hline
\end{tabular}

*S.D. = standard deviation. 


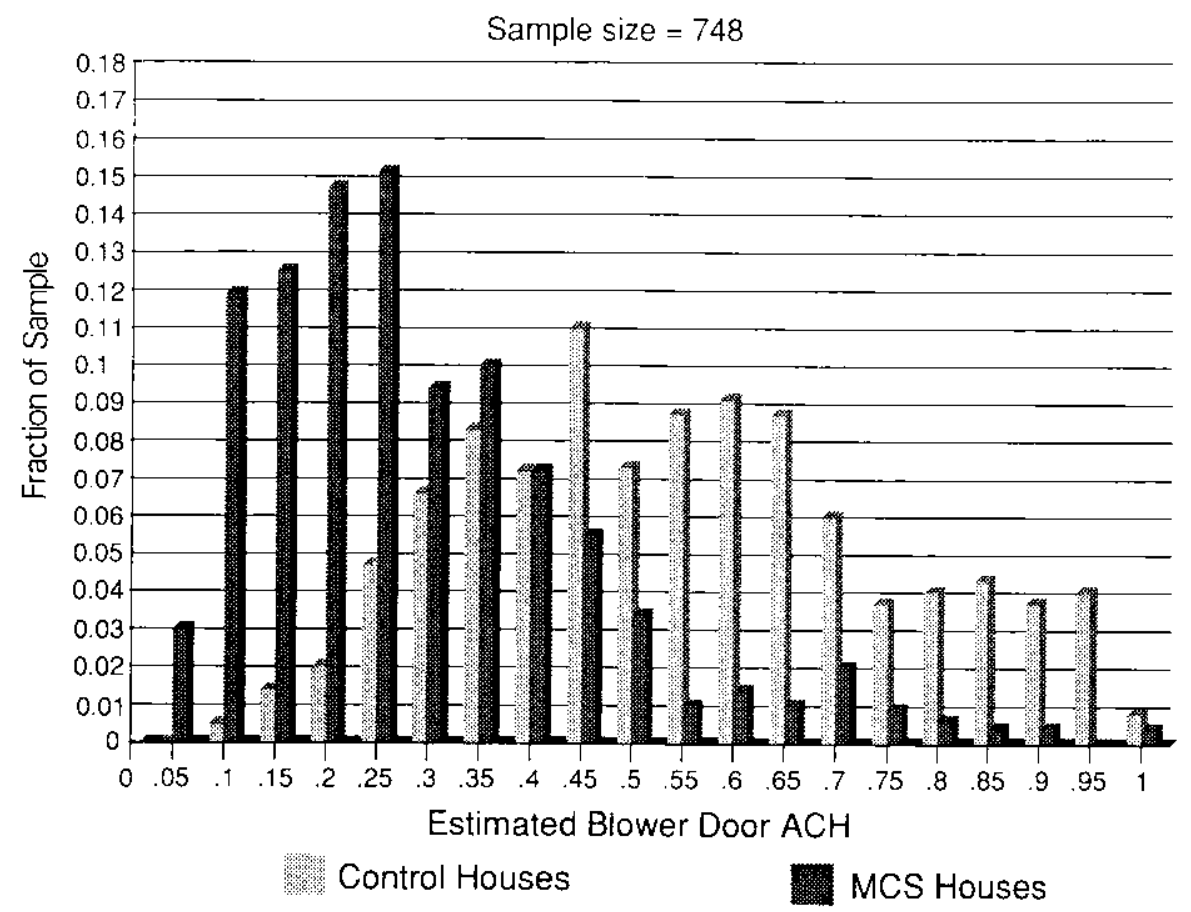

Fig. 6. Frequency distribution of estimated blower-door air change rates.

place was both warmer and less windy in the Pacific Northwest than the long-term average weather conditions. When the blower-door correlation is used with the actual Seattle weather data, the LBL algorithm predicts an average air change rate for the houses of 0.41 $\mathrm{ACH}$. Thus, it appears that, in the end, the two tests can be shown to give average air change estimates within roughly $20 \%$ of each other provided that actual weather data is used and the PFT test procedures are carefully planned and executed. However, the disagreement on individual cases is very great and is not yet resolved. It also should be pointed out that the two procedures measure different characteristics of air leakage. The blower-door test estimates that "thermally relevant" level of air change while the PFT essentially estimates the rate of dilution of a tracer gas. Thus, the two tests measure different quantities (average $\mathrm{ACH}$ and harmonic average $\mathrm{ACH}$ ) and should not be expected to agree better than within about $20 \%$ [15].

Regardless of the infiltration test used, we conclude that the average RSDP control house will have an air change rate of about 0.4 air changes per hour under normal weather conditions in the Pacific Northwest. But, how valuable is knowledge of the average air change rate? One fact that both the blower-door correlation and PFT test agree on is this: the relative air leakage of the houses vary tremendously. Figure 6 shows the blower-door correlation estimated air change rates for the RSDP and control houses. The shape of the two distributions are quite different. The RSDP distribution reflects the fact that these houses were built to be tight and generally achieved that goal. The control group shows a more normal distribution. However, in either case, the air change rate of individual houses varies $10: 1$.

The analysis also found that both the PFT and blower-door tests showed significant differences around the four states. Specifically, results showed Oregon homes to be leakiest and Montana ones to be tightest. This is consistent with expectations since builders in cold climates are typically most familiar with tight construction techniques. The average blower-door and PFT tests results for the control houses in each state are compared in Fig. 7.

\section{UTILIZATION OF AIR-TO-AIR HEAT EXCHANGERS}

Ninety-eight percent of the MCS houses in the RSDP program had air-to-air heat ex- 


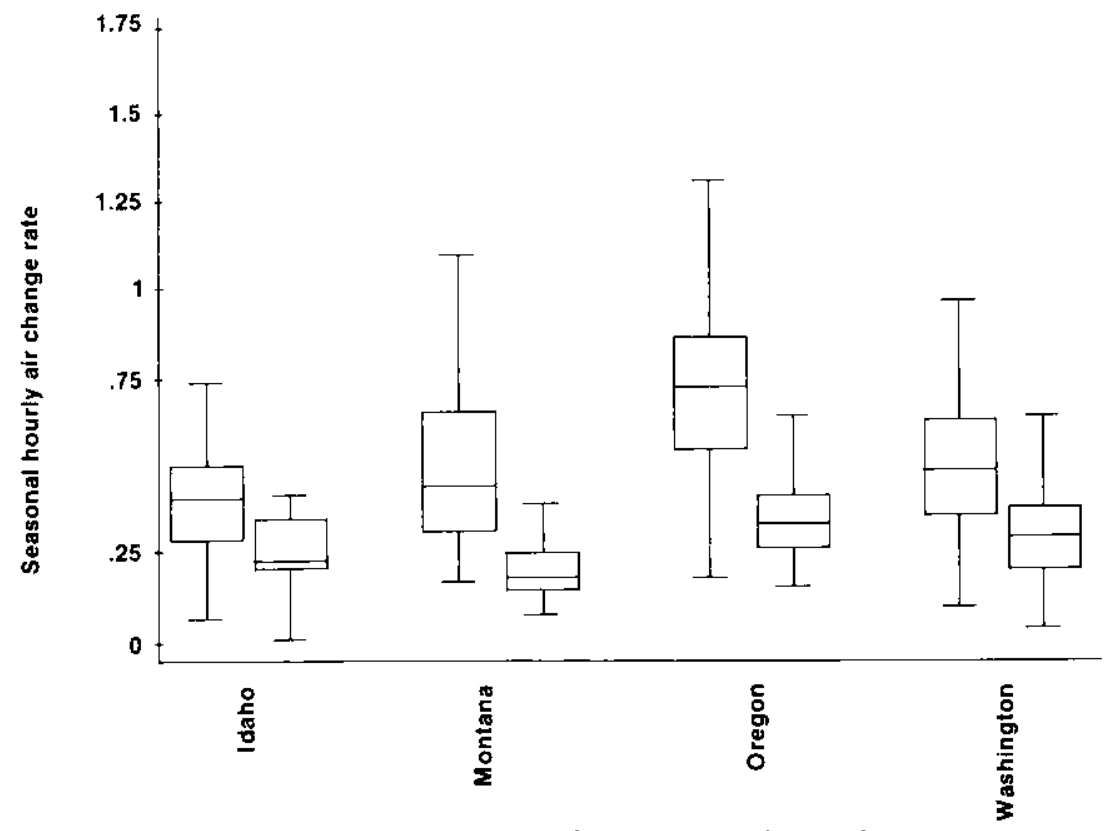

Fig. 7. Fan pressurization and PFT air change rate estimates by state.

changers, or heat recovery ventilators (HRVs) installed to provide adequate ventilation. These were designed to provide indoor ventilation up to 0.5 air changes per hour when operated continuously. However, HRV field test data from the program have suggested that achieved flow rates are significantly below design specifications [16]. Monitored winter season flow rates for well-engineered HRV installations in Montana have shown an average mechanical ventilation rate of $0.41 \mathrm{ACH}$ when operated continuously [17]. However, occupants of the MCS houses have indicated that continuous operation of the HRVs is not common practice.

Occupant survey data from the MCS houses in the program have shown that most occupants use the units $4-8$ hours per day. The ELCAP program which actually measured hourly HRV utilization rates found an average utilization rate of 8.5 hours in 29 homes [18]. Based on analysis of an occupant survey of 269 RSDP homes with HRVs, the average use of the units was estimated to be about 9.4 hours per day [19]. However, both in the RSDP and ELCAP data, the usage patterns are strongly bimodal; $42 \%$ of the RSDP group used the machines $1-4$ hours per day and $5 \%$ reported that they never operated the HRVs at all. On the other hand, a large group, $30 \%$, reported using the machines in excess of 18 hours per day. The bimodal distribution suggests an "on-off" pattern of use. Some owners use the machines most of the time; others seldom turn them on.

\section{ANALYSIS OF LIFESTYLE FACTORS ASSOCIATED WITH SPACE HEATING}

Early investigations of monitored residential energy use such as the Twin Rivers study noted that otherwise identical residential dwellings can have 2:1 differences in space heat energy consumption [20]. Since that time it has become widely accepted that occupant effects may be responsible for a great portion of the variation of energy use observed in residential buildings [21]. Analysis of the RSDP data reinforces these findings. We discovered that the range of normalized space heat consumption in the monitored RSDP houses was very large. Space heat consumption per unit floor area varied $44: 1$ in the control houses even though all were built between 1982 and 1984. Even in the MCS houses, which were designed to be thermally similar, space heat electricity consumption normalized by floor area varied 14:1. As we have seen, with the level of available data, statistical models are unable to explain more than about half of the variation. Some of these differences can be attributed to deficient climatic data (no solar, wind or ground 
temperature data) or physical differences in the houses from their descriptions, errors in data collection, omitted variables, and lack of an appropriate statistical model.

Even so, it seems likely that a sizeable portion of the variation is related to occupant behavior. This behavior is complex in the way in which it relates to building thermal performance. Occupant response to thermal conditions include: numbers of occupants and their location and schedules, thermostat setting and adjustment over time, zoning of interior rooms with multiple thermostat settings, opening and closing of interior and exterior doors and windows, operation of draperies over windows, use of exhaust fans or other forms of induced mechanical ventilation and alteration of the building structure or insulation levels over time.

Subsequent analysis of the RSDP data using a two-way analysis of variance model (ANOVA) revealed that space heat consumption is positively related to domestic hot water consumption. The hot water electricity consumption turned out to be a positive indicator for the relative level of space heat use. We estimated an ANOVA model on the residuals from eqn. (5) against estimated internal heat gains and domestic hot water electricity consumption:

$$
\begin{gathered}
\text { Residual }=-1741+0.57\left(Q_{\mathrm{dhw}}\right) \\
{[4.43]} \\
-0.13\left(Q_{\mathrm{int}}\right) \\
{[1.45]}
\end{gathered}
$$

where

Residual = actual monitored space heating electricity minus the estimate from eqn. (5)

$Q_{\text {int }}=$ total estimated intermal heat gains released over period ( $\mathrm{kWh}$ )

$Q_{\mathrm{dhw}}=$ the domestic hot water $\mathrm{kWh}$ used per household occupant over the monitoring period.

The partial $F$-ratios were 19.60 for the hot water variable and 2.09 for estimated internal gains. The $F$-ratios for the hot water variable indicates a very significant relationship. The model reveals that houses with high levels of hot water energy consumption are also more likely to use additional space heat electricity. The model in the above equation helped to explain an additional $8 \%$ of the variation in the residuals from the previous regression. Once the hot water variable is added, the estimate for internal gains assumes the proper negative sign, although it is only significant at an $80 \%$ level.

We postulate that the relationship between space heat and hot water electricity consumption is primarily due to hot water demand functioning as a proxy for relative household occupancy. When hot water energy consumption is normalized by the number of household occupants, such a parameter indicates relative occupancy levels and the tendency perhaps for energy consumptive behavior itself. In general, all three of the major end uses of electricity in the RSDP houses are related. Figure 8 presents a scatterplot matrix of annual total, space heating, hot water and appliance electricity consumption in the homes. Although a great deal of scatter is evident, the plots reveal a strong relationship between appliance and hot water energy use and a lesser relationship between hot water and space heat consumption.

These results suggest caution in developing conclusions concerning building energy use that are based on simple physical models. The analysis shows that buildings with high levels of non-space heat electricity (and associated high levels of internal heat gains) are likely to have elevated space heating budgets as well. Such results indicate the relative importance of such "lifestyle" factors in accurate estimation of space heating energy use and the need for further research to quantify the physical processes involved.

\section{IMPLICATIONS FOR FUTURE RESEARCH}

Research lessons from the RSDP program have indicated a number of recommendations/directions for future building energy monitoring research. These are briefly summarized below.

\section{Program design}

George Box has said that, "the only way to find out what will happen when a complex system is disturbed is to disturb the system, not merely to observe it passively." This is pertinent wisdom for residential energy monitoring projects. Often, more can be learned from a well-designed investigation than 


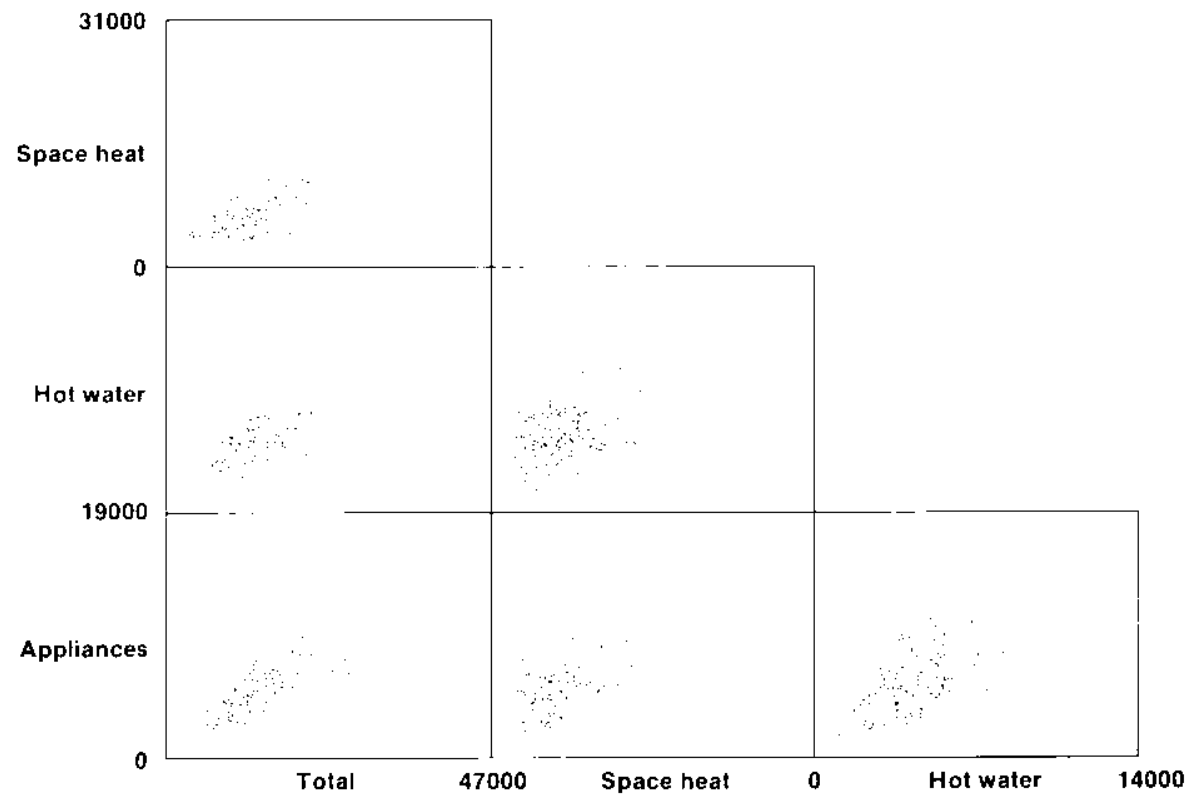

Fig. 8. Scatter plot matrix of electricity end-use consumption in RSDP houses.

'natural experiments' of convenience. Parameter boundary conditions of interest should be reproduced in a planned study without each being related to some other change in the other variables. A good method for largescale monitoring projects would be to use a small controlled study to supplement the overall monitoring effort and later analysis. Utilization of efficient experimental designs such as an orthogonal Latin-square structure evaluated by analysis of variance can allow a large number of influences to be assessed with a minimum number of experiments. Through such methods it will be possible to much more accurately isolate the individual effects.

Occupant-related variation in building energy consumption is one aspect that does not readily lend itself to this type of treatment. This has the consequence of substantially increasing sample sizes required for statistically significant conclusions. Of great interest, however, would be a study tracking families as they moved from one dwelling to the next. In this way it would be possible to isolate energy-related occupancy effects from those of a physical nature.

\section{Monitoring}

Projects collecting simple end-use metering data should insure that site-specific weather data are collected. Ambient temperature and insolation measurements are fundamental to later analysis. Also, wind data may substantially increase the accuracy of infiltrationrelated estimates. Measurement of multiple zone temperatures is recommended, particularly when the house contains a basement, sunspace or other readily closed-off sections. End-use metering should consider the following level of disaggregation at a minimum: space heat, space cooling, hot water, and interior and non-interior appliance electricity consumption. Both blower-door and tracergas testing for houses are recommended to determine relative rates of air leakage.

\section{Simulation analysis}

For simulation purposes, a single zone model of residential buildings appears to have serious drawbacks. The RSDP program gives evidence that basements may not be conditioned to the same level as the rest of the structure, even when heated. Also, houses heated with baseboard units lend themselves to zonal heating of the buildings; survey data from the Northwest suggest that approximately $20 \%$ of residential floor area is unconditioned at any given time.

There is evidence of reciprocity between the level of internal heat gains and the thermostat setpoints in residential buildings. This occupancy-related characteristic also likely extends to zoning behavior. Thus, simulation 
analysis of residential building thermal performance should consider two operationrelated prototypes for conservation-measure assessment and develop appropriate weights for each based on surveyed characteristics of the population:

\begin{tabular}{lllll}
\hline Prototype & $\begin{array}{l}\text { Occupancy } \\
\text { level }\end{array}$ & $\begin{array}{l}\text { Thermostat } \\
\text { settings }\end{array}$ & $\begin{array}{l}\text { Internal Zoning } \\
\text { gains }\end{array}$ & \\
\hline Type I & Low & $\begin{array}{l}\text { Long } \\
\text { setbacks }\end{array}$ & Low & High \\
Type II & High & $\begin{array}{l}\text { Short } \\
\text { setbacks }\end{array}$ & High & Low \\
\hline
\end{tabular}

\section{Analysis methods}

Much can be learned about the theoretical advantages and disadvantages of various residential energy data analysis techniques through the use of detailed computer simulations to produce synthetic data on which the analysis methods can be tested. Since actual solutions are known, the accuracy and bias of the various analytical tools can be reasonably assessed.

\section{CONCLUSIONS}

Monitored space heat savings of the MCS over conventional new houses averaged 27.5 $\mathrm{kWh} / \mathrm{m}^{2}$ in the RSDP project. When normalized by temperature differences the MCS buildings are shown to have a very low level of auxiliary heat consumption $-6.3 \mathrm{~W} /{ }^{\circ} \mathrm{C}$ day $\mathrm{m}^{2}$. However, the control group buildings in the RSDP project were relatively efficient as well, using only $11.4 \mathrm{~W} /{ }^{\circ} \mathrm{C}$ day $\mathrm{m}^{2}$. Generally the savings of the MCS have been less than we originally estimated in formulating the Model Conservation Standards, almost entirely due to the rather surprising performance of the current construction practice control group buildings. Evidence indicates that the control group houses were considerably more airtight than had been assumed in designing the MCS. However, the savings from the other efficiency measures are still well within the range that makes the standards economically attractive. We conclude that:
(1) The most powerful explanatory factor for the difference in space heating consumption in the group of houses is the estimated overall heat loss coefficient for that building and the cumulative temperature difference between inside and ambient conditions.

(2) Heating system type plays a large role in determining the relative efficiency of electrically heated houses. Forced-air heating systems perform poorly relative to other types. Homes using heat pumps showed lower space heat electricity consumption. Homes heated primarily with a wood stove showed much lower electric space heat consumption.

(3) Larger homes tend to show lower normalized space heat indicating that normalizing space heat conditioning needs on the basis of floor area will introduce a bias in the results. Physically, this bias stems from the decreasing ratio of exterior envelope area to floor area as floor area increases.

(4) Based on blower-door and perfluorocarbon tracer gas tests, control homes in the RSDP project are relatively tight, exhibiting an average natural air change rate of only about 0.4 air changes per hour.

(5) The infiltration rates in current practice Northwest houses are so variable that dependence on "natural infiltration" in houses for sufficient ventilation air seems inadequate. Many houses that did not attempt tight construction still achieved very low levels of air leakage.

(6) The average temperature in the main living zone of the energy-efficient houses was warmer by $0.8^{\circ} \mathrm{C}$ than in the control group houses. Much of this difference was found to be attributable to the difference in heat loss coefficients for the MCS and control houses and solar availability from one climate zone to the next.

(7) Air-to-air heat exchangers are not typically used on a continuous basis. Average utilization is only about 9 hours per day. Usage is best characterized as bimodal with a large group with nearly continuous use against another large section of the sample who seldom ran the machines at all.

(8) Houses with fireplaces showed greater estimated specific leakage areas and higher normalized consumption of space heat. Based on blower-door tests, much of this difference was attributed to increased air leakage in houses with this design feature. 
(9) The primary electricity end uses in residential buildings are related; homes using more electricity for domestic hot water heating are also likely to use more electricity for space heat. There are strong indications that space conditioning needs are influenced by dwelling occupancy levels.

\section{ACKNOWLEDGEMENTS}

A number of people have helped in preparing and analyzing the data for this report. Special thanks to Alan Meier, Bruce Nordman, and Ed Vine of the Lawrence Berkeley Laboratory, Tom Eckman at the Northwest Power Planning Council, Jeff Harris at the Bonneville Power Administration, Richard Byers at the Washington State Energy Office and Larry Palmiter of Ecotope Inc.

\section{REFERENCES}

1 T. Eckman, How the standards grew: the blueprint, Northwest Energy News, 3 (2) (1984).

2 A. Meier et al., A Thermal Analysis of Homes in Bonneville Power Administration's Residential Standards Demonstration Program, Lawrence Berkeley Laboratory, Berkeley, CA, September, 1986.

3 J. F. Busch and A. K. Meier, Monitored Performance of New, Low-Energy Homes: Updated Results from the BECA-A Data Base, LBL-18306, Lawrence Berkeley Laboratory, Berkeley, CA, 1986.

4 Swisher et al., Passive Solar Performance: Summary of the 1982 - 1983 Class B Results, SERI/ SP-271-2362, Solar Energy Research Institute, Golden, CO, 1984.

5 Jakob et al., SP43 Evaluation of system options for residential forced-air heating, ASHRAE Trans., 92 (Part 2) (1986).

6 J. W. Tukey, Exploratory Data Analysis, AddisonWesley, Reading, MA, 1977.

7 B. Nordman and A. Meier, Outdoor-indoor tem. perature relationships, Proc. 1988 ACEEE Summer Study on Energy Efficiency in Buildings, American Council for an Energy Efficient Economy, Washington, DC, 1988.

8 F. Mosteller and J. W. Tukey, Data Analysis and Regression, Addison Wesley, Reading, MA, 1977.
9 M. H. Sherman and M. P. Modera, Comparison of measured and predicted infiltration rates using the LBL infiltration model, Measured $A$ ir Leakage in Buildings, ASTM STP-904, American Society for Testing and Materials, Philadelphia, PA, 1984.

10 D. S. Parker, Use of monitored data to characterize typical internal heat gain levels in residential buildings, Proc. 13th National Passive Solar Conference, American Solar Energy Society, Cambridge, MA, 1988.

11 E. E. Leamer, Global sensitivity results for generalized least squares estimates, J. Am. Stat. Assoc., (Dec.) (1984).

12 R. Byers and L. Palmiter, Analysis of agreement between predicted and monitored annual space heat use for a large sample of homes in the Pacific Northwest, Proc. 1988 ACEEE Summer Study on Energy Efficiency in Buildings, American Council for an Energy Efficient Economy, Washington, DC, 1988.

13 E. Hirst, R. Goeltz and D. Trumble, Electricity Use and Savings in the Hood River Conservation Project, ORNL/CON-231, Oak Ridge National Laboratory, Oak Ridge, TN, 1987.

14 Northwest Conservation and Electric Power Plan, Vol. II, Northwest Power Planning Council, Portland, OR, 1986.

15 M. H. Sherman, Analysis of Errors A ssociated with Passive Ventilation Measurement Techniques, $L B L$ 23088, Lawrence Berkeley Laboratory, Berkeley, CA, 1987.

16 L. Lambert and C. Cramer, Testing of air to air heat exchanger flow rates for the residential standards demonstration program, Proc. Conservation in Buildings: Northwest Perspective, Butte, MT, 1985.

17 L. Palmiter and M. Toney, Field performance measurement of heat recovery ventilators in Montana, Proc. 12th National Passive Solar Conference, American Solar Energy Society, Portland, OR, 1987.

18 K. Drost, Analysis of Air to Air Heat Exchanger Performance Data Taken Under the Residential Demonstration Program, Pacific Northwest Laboratory, Richland, WA, 1986.

19 E. V. Vine, Air to Air Heat Exchangers and the Indoor Environment, $L B L-22908$, Law rence Berkeley Laboratory, Berkeley, CA, February, 1987.

20 R. H. Socolow (ed.), Saving Energy in the Home: Princeton's Experiments at Twin Rivers, Ballinger Publishing Co., Cambridge, MA, 1978.

21 W. Kempton and M. Neiman (eds.), Energy Efficiency: Perspectives on Individual Behavior, American Council for an Energy Efficient Economy, Washington, DC, 1987. 